\title{
New Report on Two Species of Hippolytid Shrimps (Crustacea: Decapoda: Caridea) Collected at Sea Cucumber Farm, East Sea, Korea
}

\author{
Chu Lee ${ }^{1}$, Myung-mo Nam¹, Hyun Sook Ko², Kyu Hyun Lee ${ }^{3, *}$ \\ ${ }^{1}$ East Sea Fisheries Research Institute, National Fisheries Research \& Development Institute, \\ Gangneung 210-861, Korea \\ ${ }^{2}$ Department of Biological Sciences, Silla University, Busan 617-736, Korea \\ ${ }^{3}$ Tidal Flat Research Institute, National Fisheries Research \& Development Institute, \\ Gunsan 573-882, Korea
}

\begin{abstract}
Two species of hippolytid shrimps, Eualus kuratai Miyake and Hayashi, 1967 and Heptacarpus igarashii Hayashi and Chiba, 1989, were collected at a sea cucumber farm from the East Sea. These species are described and illustrated for the first time in Korea. Eualus kuratai is closely related to E. middendorffi; however, it lacks a dorsomedian spine on the fourth and fifth abdominal somites. Heptacarpus igarashii can be easily distinguished from other Korean Heptacarpus species due to its short rostrum that lacks ventral teeth on margin. This report extends the previously known ranges from Japan and Korea. In Korea, both genera, Eualus and Heptacarpus, have seven species according to the present report, respectively; moreover, hippolytid shrimps now consist of 31 species of nine genera.
\end{abstract}

Keywords: Hippolytid, shrimp, Eualus kuratai, Heptacarpus igarashii, Korea

\section{NTRODUCTI ON}

The genus Eualus Tallwitz, 1892 is characterized by carapace without a supraorbital spine and with the third maxilliped having an exopod and no arthrobranch (Kim, 2012). It includes six species in Korea: E. biunguis (Rathbun, 1902), E. leptognathus (Stimpson, 1860), E. macilentus (Krøyer, 1841), E. middendorffi Bražnikov, 1907, E. sinensis (Yu, 1931), and E. spathulirostris (Yokoya, 1933). The genus Heptacarpus Holmes, 1900 is characterized by carapace without supraorbital spine and an elongated third maxilliped without an exopod (Kim, 2012). It consists of six species: $H$. acuticarinatus Komai and Ivanov, 2008, H. futilirostris (Bate, 1888), H. geniculatus (Stimpson, 1860), H. jordani (Rathbun, 1902), H. pandaloides (Stimpson, 1860), and H. rectirostris (Stimpson, 1860) (see The Korean Society of Systematic Zoology, 1997; Cha et al., 2001; Yang and Kim, 2005; Kim and Choi, 2006; Kim et al., 2006; Kim, 2012).

During a survey in the area of sea cucumber farms, a number of small crabs and shrimps were collected. Among the shrimps caught, two species of hippolytid shrimps, Eualus kuratai Miyake and Hayashi, 1967 and Heptacarpus igarashii Hayashii and Chiba, 1989, are new to the Korean shrimp fauna. Therefore, they are described and illustrated with color photographs.

Postorbital carapace length is abbreviated as "CL". CL is an indication of the size of the specimen and is measured from the posterior margin of the orbit to the posterior middorsal margin of the carapace. Specimens were preserved in 95\% ethanol. The materials examined in this study were deposited at Silla University in Busan, Korea.

\section{SYSTEMATI C ACCOUNTS}

Order Decapoda Latreille, 1803

Superfamily Alpheoidea Rafinesque, 1815

Family Hippolytidae Bate, 1888

Genus Eualus Thallwitz, 1892 (c) This is an Open Access article distributed under the terms of the Creative Commons Attribution Non-Commercial License (http://creativecommons.org/ licenses/by-nc/3.0/) which permits unrestricted non-commercial use, distribution, and reproduction in any medium, provided the original work is properly cited.

pISSN 2234-6953 eISSN 2234-8190

\section{*To whom correspondence should be addressed \\ Tel: 82-63-472-8600, Fax: 82-63-467-2675}

E-mail: celllove81@gmail.com

Copyright $(\mathcal{C}$ The Korean Society of Systematic Zoology 
1*Eualus kuratai Miyake and Hayashi, 1967 (Figs. 1, 2) Eualus kuratai Miyake and Hayashi, 1967: 253, fig. 3; Igarashi, 1969: 1, Pl. 1, fig. 2j; Bauer, 1984: 207 (list); Hayashi, 1993: 313, figs. 244e, 245d; Komai and Komatsu, 2009: 533, fig. 21A; De Grave and Fransen, 2011: 417 (list).

Material examined. Korea: $1 \sigma^{71}$ (CL $8.08 \mathrm{~mm}$ ), Daejin (Yeongdeok), 6 May 2012, Lee SH, at a sea cucumber farm in approximately $38 \mathrm{~m}$ depth.

Description. Body (Figs. 1A, 2) small size. Rostrum (Fig. $1 \mathrm{~A}, \mathrm{~B})$ nearly straight, directed forward, exceeding distal margin of antennular peduncle, dorsal margin with 4 small teeth, including 3 teeth on rostrum proper and 1 postrostral tooth, ventral margin with 6 small teeth. Carapace (Fig. 1A, B) shorter than rostrum; antero-lateral angle with well developed antennal spine; pterygostomian spine present. Abdomen (Fig. 1A) dorsally rounded. Pleuron of third somite with obtusely pointed, but both fourth and fifth somites entirely smooth, without dorsomedian spine; pleuron of fifth somite pointed posteriorly. Telson (Fig. 1A, K) as long as sixth somite, with 4 pairs of spines; 1 pair of plumose setae and 2 pairs of spines terminally, inner pair longer than outer one. Eye (Fig. 1A) cylindrical; eyestalk slightly longer than cornea. Antennular peduncle (Fig. 1C) extending to middle point of rostrum; stylocerite absent. Antennal scale (Fig. 1D) long, extending to rostral apex by inner angle of lamellar tip; equal in breadth at both of proximal and distal parts. Third maxilliped (Fig. 1A, E, E') overreaching tip of antennular peduncle; exopod well developed. First pereopod (Fig. 1A, F) moderately stout, reaching to second segment of antennular peduncle. Second pereopod (Fig. 1A, G) slender, carpus dividing into 7 articles; chela small. Third pereopod (Fig. $1 \mathrm{~A}, \mathrm{H})$ reaching forward nearly as far as lateral spine of antennal scale; merus with 3 lateral spines. Fourth pereopod (Fig. 1A, I) similar to third pereopod; merus with 4 lateral spines. Fifth pereopod (Fig. 1A, J) as in fourth pereopod.

Color. Dense red spots over transparent body with scattering of yellow spots. Antennal scale and telson entirely red (Fig. 2).

Distribution. Japan, Between Rishiri Island and Rebun Island, Hokkaido, 100-150 m deep (Miyake and Hayashi, 1967), and now Korea, Daejin in approximately $38 \mathrm{~m}$ depth.

Remarks. This specimen generally agrees well with the original description of E. kuratai by Miyake and Hayashi (1967), which is the seventh species of the genus Eualus described from Korean waters. Further, although this species is most similar to E. middendorffi, it differs in the following characters. The mean body length (female) of $E$. ku- ratai is $30 \mathrm{~mm}$ compared to $41-65 \mathrm{~mm}$ (female) for E. middendorffi. Moreover, the dorsomedian spine is absent on the fourth and fifth abdominal somites in the former, whereas it is present in the latter (Miyake and Hayashi, 1967).

Genus Heptacarpus Holmes, 1900

\section{${ }^{2 *}$ Heptacarpus igarashii Hayashi and Chiba, 1989 (Figs. 3, 4)}

Heptacarpus igarashii Hayashi and Chiba, 1989: 71, figs. 1-3; Hayashi, 1992: 270, figs. 226a, 227a, 228a, 229; De Grave and Fransen, 2011: 420 (list).

Material examined. Korea: 1 우 (CL $6.55 \mathrm{~mm}$ ), Daejin (Yeongdeok), 6 May 2012, Lee SH, at a sea cucumber farm in approximately $38 \mathrm{~m}$ depth.

Description. Body (Figs. 3, 4) small size. Rostrum (Fig. 4A, B) short and spiniform, nearly straight and apically downward, reaching slightly beyond end of eye, dorsal margin with 4 teeth, including 2 teeth on rostrum proper and 2 postrostral teeth, ventral margin unarmed. Carapace (Fig. 4A, B) smooth, about 3 times as long as rostrum; suborbital margin rounded; antennal spine sharp and larger. Abdomen (Fig. 4A) smooth. Pleura of fourth and fifth somites pointed posteriorly, spine of fourth somite small. Telson (Fig. 4A, K) shorter than uropod, with 3 pairs of dorsal spines; posterior margin ending in acute tip, with 3 pairs of unequal spines. Eye (Fig. 4A) cylindrical; cornea slightly shorter than eyestalk. Antennular peduncle (Fig. 4C) reaching to midpoint of antennal scale; first segment longer than distal two segments combined, with 3 marginal spinules; second and third segments subequal, each with single, rather large marginal spine; stylocerite reaching beyond slightly distal margin of first segment. Antennal scale (Fig. 4D) long, 3.0-3.5 times as long as broad. Third maxilliped (Fig. 4A, E, E') reaching beyond antennal scale by distal two segments; with rod-like epipod. First pereopod (Fig. 4A, F) robuster, reaching beyond antennal scale by distal half of palm; chela less than twice as long as carpus; merus shorter than chela, without subterminal spine. Second pereopod (Fig. 4A, G) slender, reaching beyond antennal scale by half of carpus, carpus dividing into 7 articles; chela small; ischium longer than merus. Third pereopod (Fig. 4A, H) reaching beyond antennal scale by dactylus or distal half of propodus; merus with single subterminal spine; propodus as long as merus, both with about 10 pairs of spinules on posterior margins; dactylus biunguiculate, with 4 spinules on posterior margin. Epipod present on first 3 pereopods. Fourth pereopod (Fig. 4A, I) falling short of end of antennal scale; merus with single subter-

Korean name: ${ }^{1 *}$ 긴뿔갯가꼬마새우(신칭), ${ }^{2 *}$ 대진좁은뿔꼬마새우(신칭) 

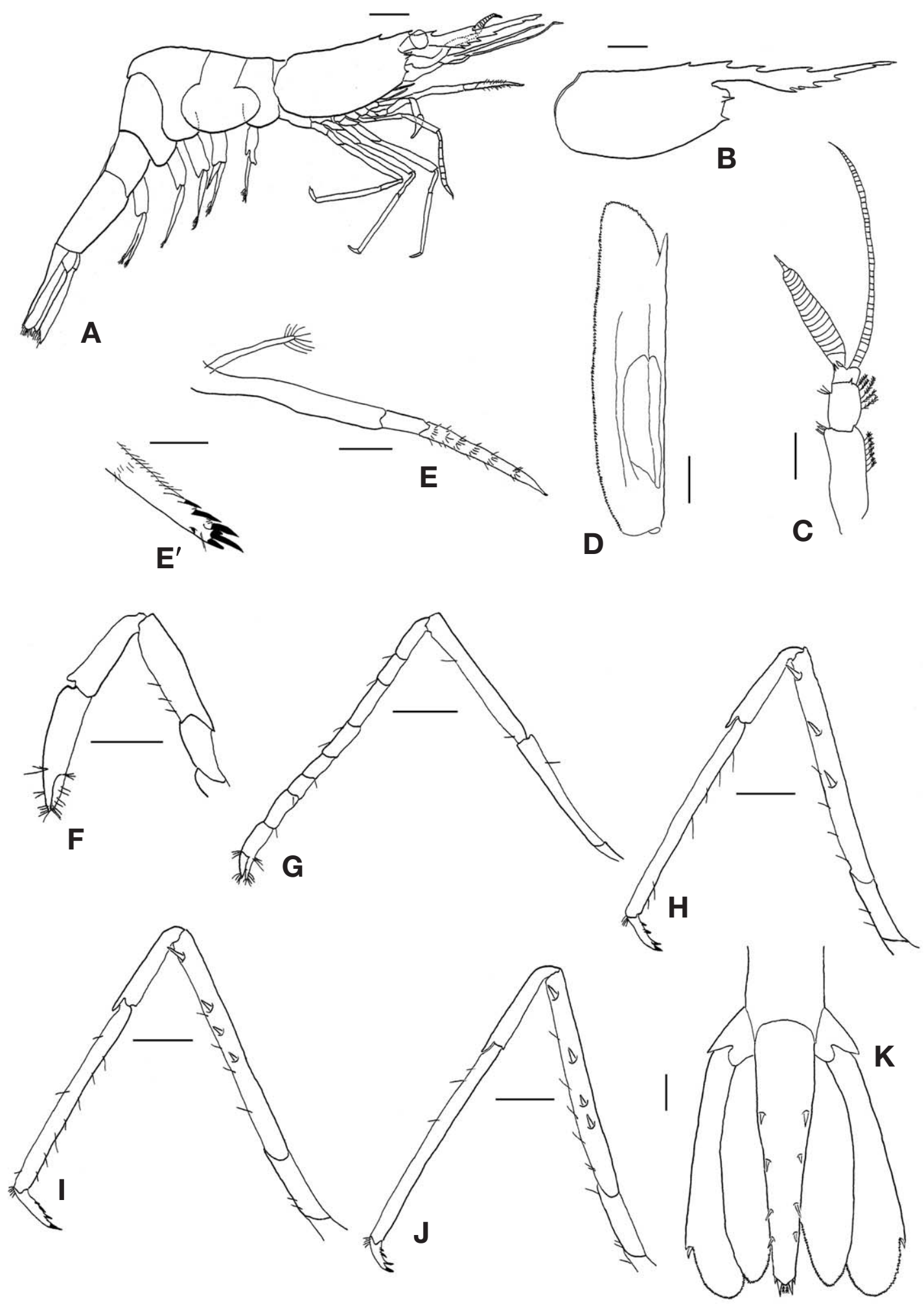

Fig. 1. Eualus kuratai, male (CL $8.08 \mathrm{~mm})$. A, Habitus, lateral; $B$, Carapace, lateral; C, Left antennule, dorsal; $D$, Right antennal scale, dorsal; E, Left third maxilliped, lateral; E', Left third maxilliped, distal segment; F, Right 1st pereopod, lateral; G, Left 2nd pereopod, lateral; H, Left 3rd pereopod, lateral; I, Left 4th pereopod, lateral; J, Left 5th pereopod, lateral; K, Telson, dorsal. CL, length of posterior margin of the orbit to the posterior middorsal margin of the carapace. Scale bars: $\mathrm{A}, \mathrm{B}=2 \mathrm{~mm}, \mathrm{C}-\mathrm{K}=1 \mathrm{~mm}$, $\mathrm{E}^{\prime}=0.5 \mathrm{~mm}$. 


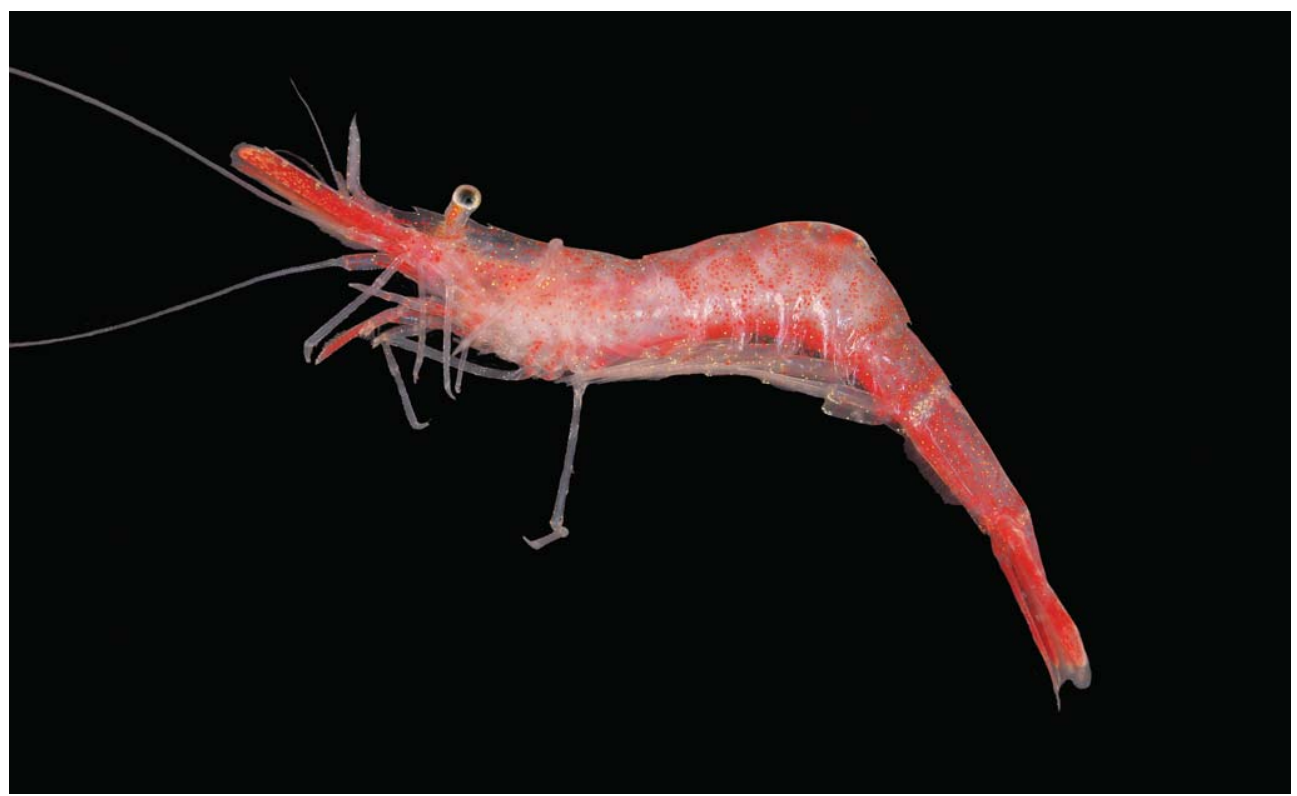

Fig. 2. Eualus kuratai, male $(\mathrm{CL} 8.08 \mathrm{~mm})$. $\mathrm{CL}$, length of posterior margin of the orbit to the posterior middorsal margin of the carapace.

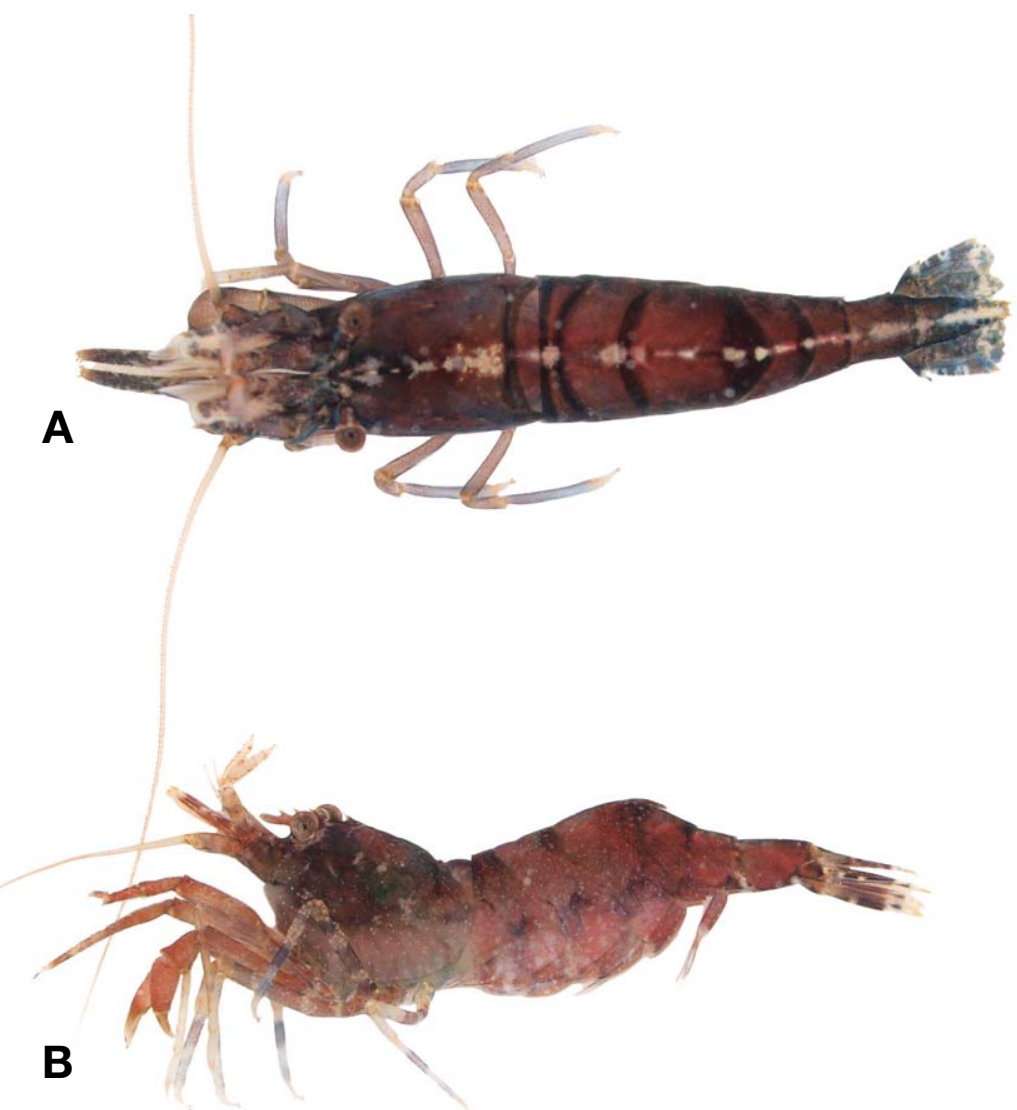

Fig. 3. Heptacarpus igarashii, ovigerous female ( $C L 6.55 \mathrm{~mm})$. A, Dorsal view; $B$, Lateral view. $C L$, length of posterior margin of the orbit to the posterior middorsal margin of the carapace. 

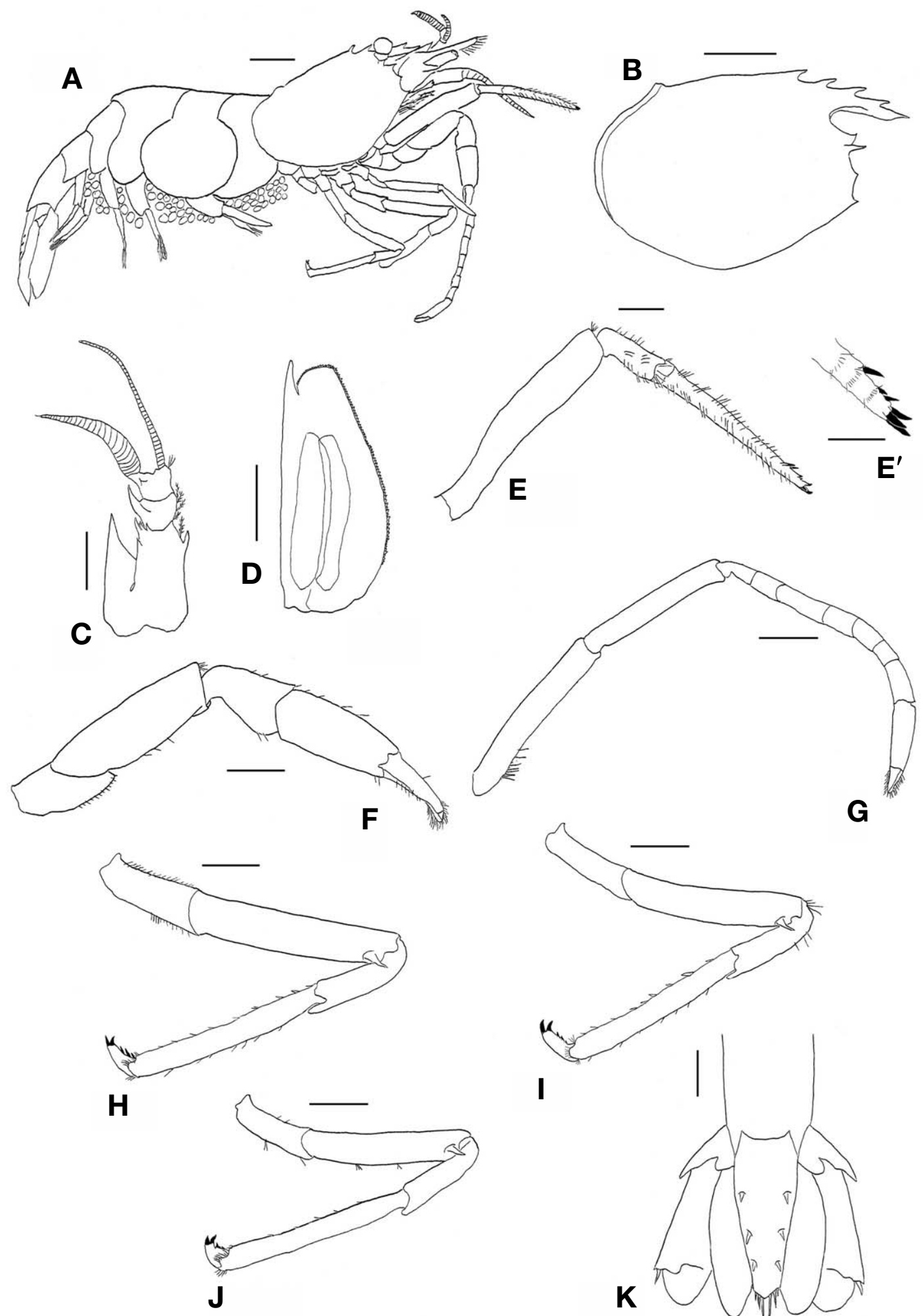

G

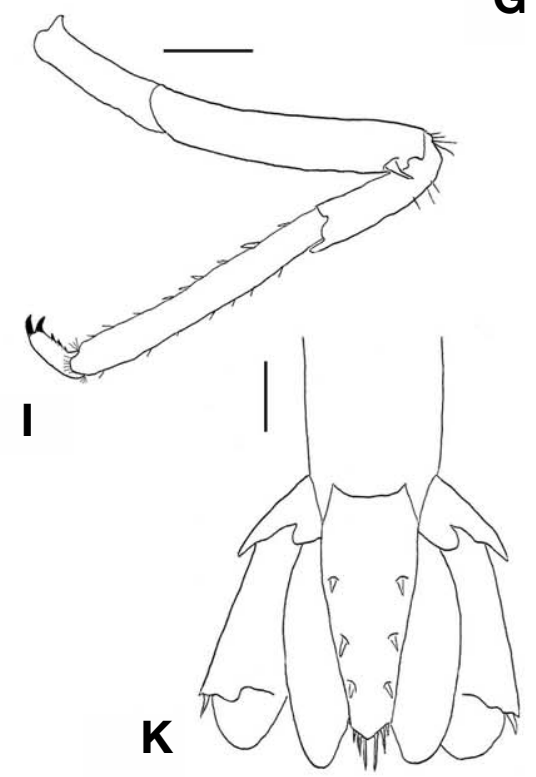

Fig. 4. Heptacarpus igarashii, ovigerous female (CL $6.55 \mathrm{~mm})$. A, Habitus, lateral; $B$, Carapace, lateral; $C$, Left antennule, dorsal; D, Left antennal scale, dorsal; E, Right third maxilliped, lateral; E', Right third maxilliped, distal segment; F, Right 1st pereopod, lateral; G, Right 2nd pereopod, lateral; H, Right 3rd pereopod, lateral; I, Right 4th pereopod, lateral; J, Right 5th pereopod, lateral; $\mathrm{K}$, Telson, dorsal. $\mathrm{CL}$, length of posterior margin of the orbit to the posterior middorsal margin of the carapace. Scale bars: $\mathrm{A}, \mathrm{B}=2$ $\mathrm{mm}, \mathrm{C}-\mathrm{K}=1 \mathrm{~mm}, \mathrm{E}^{\prime}=0.5 \mathrm{~mm}$. 
minal spine; propodus as long as merus, both shorter than those of third pereopod. Fifth pereopod (Fig. 4A, J) reaching to end of antennular peduncle, merus with 1 small subterminal spine, shorter than that of fourth pereopod; propodus longer than merus, as long as that of fourth pereopod. Color. Brownish body with dark brown stripes on abdomen dorsally. Tail fan dark brown (Fig. 3).

Distribution. Japan (Hayashi and Chiba, 1989), and now Daejin in approximately $38 \mathrm{~m}$ depth.

Remarks. This specimen fits well with the description of H. igarashii by Hayashi and Chiba (1989). With regard to the short rostrum, this species closely resembles $H$. futilirostris, $H$. rectirostris and $H$. jordani from Korean waters. However, the absence of ventral teeth on the short rostrum (H. futilirostris and $H$. rectirostris with 2-3 teeth and $H$. jordani with 1 tooth) can be easily distinguished from these three species. It is the seventh species of the Heptacarpus described from Korean waters.

\section{ACKNOWLEDGMENTS}

This research was carried out as a part of the project "The Survey of Korean Indigenous Species" supported by National Institute of Biological Resources (NIBR) of Ministry of Environment of Korea (NIBR No. 2012-02-037).

\section{REFERENCES}

Bate CS, 1888. Report on the Crustacea Macrura collected by the H. M. S. Challenger during the years 1873-76. Report of the scientific results of the voyage of the H. M. S. Challenger during the years 1873-76, Zoology, 24:1-942.

Bauer RT, 1984. Morphological trends in the genus Heptacarpus (Decapoda, Caridea) and their phylogenetic significance. Journal of Crustacean Biology, 4:201-225.

Bražnikov V, 1907. Materiaux pour server à la connaissance de la faune des mers russes de l'Est rassembles par le schooner "Storož" en 1899-1902. Mémoires de l'Académie Impériale des Sciences de St-Pétersbourg. Classe des Sciences Phisiques et Mathématiques, 20:1-185.

Cha HK, Lee JU, Park CS, Baik CI, Hong SY, Park JH, Lee DW, Choi YM, Hwang K, Kim ZG, Choi KH, Sohn H, Sohn MH, Kim DH, Choi JH, 2001. Shrimps of the Korean waters. National Fisheries Research and Development Institute, Busan, pp. 1-188.

De Grave S, Fransen CHJM, 2011. Carideorum catalogus: the recent species of the dendrobranchiate, stenopodidean, procarididean and caridean shrimps (Crustacea: Decapoda). Zoologische Mededelingen, Leiden, 85:195-589.

Hayashi KI, 1992. Prawns, shrimps and lobsters from Japan (66). Family Hippolytidae Genus Heptacarpus 3. Aquabio- logy, 14:270-274.

Hayashi KI, 1993. Prawns, shrimps and lobsters from Japan (73). Family Hippolytidae Genus Eualus 2. Aquabiology, 15:311-314.

Hayashi KI, Chiba T, 1989. Heptacarpus igarashii sp. nov. from northern Japan (Decapoda, Caridea, Hippolytidae). Bulletin of the Biogeographical Society of Japan, 44:71-76.

Igarashi T, 1969. A list of marine decapod crustaceans from Hokkaido, deposited at the Fisheries Museum, Faculty of Fisheries, Hokkaido University I. Macrura. Contribution from the Fisheries Museum, Faculty of Fisheries, Hokkaido University, 11:1-15.

Kim JN, 2012. Invertebrate Fauna of Korea. Vol. 21. No. 14. Shrimps. National Institute of Biological Resources, Incheon, pp. 1-173.

Kim JN, Choi JH, 2006. Two new records of caridean shrimps (Crustacea: Decapoda) from the Korean continental slope of East Sea. Korean Journal of Systematic Zoology, 22:5155.

Kim JN, Choi JH, Ma CW, 2006. Two hippolytid shrimps of the genus Eualus (Crustacea: Decapoda: Caridea) from Korea. Journal of Fisheries Science and Technology, 9:8390.

Komai T, Ivanov BG, 2008. Identities of three taxa of the hippolytid shrimp genus Heptacarpus (Crustacea: Decapoda: Caridea), with description of a new species from Asian waters. Zootaxa, 1684:1-34.

Komai T, Komatsu H, 2009. Deep-sea shrimps and lobsters (Crustacea: Decapoda) from northern Japan, collected during the project "Research on Deep-sea Fauna and Pollutants off Pacific Coast of Northern Japan”. In: Deep-sea Fauna and Pollutants off Pacific Coast of Northern Japan (Ed., Fujita T). National Museum of Nature and Science Monograph, 39:495-580.

Krøyer H, 1841. Udsigt over de nordiske arter af slaegten Hippolyte. Naturhistorisk Tidsskrift, 3:570-579.

Miyake S, Hayashi KI, 1967. Studies on the hippolytid shrimps from Japan, I. Revision of the Japanese species of the genus Eualus, with description of two new species. Journal of the Faculty of Agriculture, Kyushu University, 14:247-265.

Rathbun MJ, 1902. Description of new decapod crustaceans from the west coast of North America. Proceedings of the United States National Museum, 24:885-905.

Stimpson W, 1860. Prodromus descriptionis animalium evertebratorum, quae in Expeditione as Oceanum Pacificum Septentrionalem, a Republic federate missa, Cadwaladore Ringgold et Johanne Rodgers Ducibus, observavit et descripsit. Pars VIII, Crustacea Macrura. Proceedings of the Academy of Natural Sciences of Philadelphia, 1860:22-47.

The Korean Society of Systematic Zoology, 1997. List of animals in Korea (excluding insects). Academy Publishing Co., Seoul, pp. 1-489.

Yang HJ, Kim JN, 2005. New record of Heptacarpus jordani (Crustacea: Decapoda: Hippolytidae) from Korea and redescription of Heptacarpus geniculatus. Korean Journal of 
Systematic Zoology, 21:11-19.

Yokoya Y, 1933. On the distribution of decapod crustaceans inhabiting the continental shelf around Japan, chiefly based upon the materials collected by S. S. Sôyô-Maru, during the year 1923-1930. Journal of the College of Agriculture, Tokyo Imperial University, 12:1-226.
Yu SC, 1931. Description de deux nouvelles crevettes de Chine. Bulletin du Muséum National d'Historie Naturelle, 3:513516.

Received December 17, 2013 Revised February 6, 2014 Accepted February 6, 2014 